University of Miami Law School University of Miami School of Law Institutional Repository

Articles

Faculty and Deans

2011

\title{
O My Sons and Daughters, How Do I Immiserate Thee: Let Me Count the Ways
}

Kenneth M. Casebeer

University of Miami School of Law, casebeer@law.miami.edu

Follow this and additional works at: https://repository.law.miami.edu/fac_articles

Part of the Law and Economics Commons, Law and Society Commons, and the Public Policy Commons

\section{Recommended Citation}

Kenneth M. Casebeer, O My Sons and Daughters, How Do I Immiserate Thee: Let Me Count the Ways, 29 Hofstra Lab. \& Emp. L. J. 1 (2011).

This Article is brought to you for free and open access by the Faculty and Deans at University of Miami School of Law Institutional Repository. It has been accepted for inclusion in Articles by an authorized administrator of University of Miami School of Law Institutional Repository. For more information, please contact library@law.miami.edu. 


\section{ARTICLES}

\section{O MY SONS AND DAUGHTERS, HOW DO I IMMISERATE THEE: LET ME COUNT THE WAYS*}

\section{Kenneth Casebeer**}

All social deals are now off - Fair, Square, or New, all broken. The United States has apparently given up on most Americans. Secretary of the Treasury Timothy Geithner at the G-20 Summit in 2009, after all, blamed the American people for the Great Recession:

[F]or too long, Americans were buying too much and saving too little. And that's no longer an option for us or for the rest of the world. And already in the United States you can see the first signs of an important transformation here as Americans save more and as we borrow substantially less from the rest of the world. ${ }^{1}$

One might wonder just which Americans can afford to save more for Mr. Geithner. Notice the absence of the financial services involvement here in precipitating the Great Recession. But nonetheless, there is no doubt that the bailout was for the financial services. According to the Obama Administration consumer guru, Elizabeth Warren, "[w]e rescued at the top and left the bottom to kind of fend for itself, and that's reflected in the unemployment numbers. [. . . ] It saved the top of the system. It stabilized it, but not so much for families who are hard hit down on the ground, the real economy."2

\footnotetext{
* Apologies to Walt Whitman and Robert Browning.

** Professor of Law, University of Miami Law School, editor of American Labor Struggles and Law Histories (Durham: Carolina Academic Press, 2011).

1. Timothy Geithner, U.S. Sec'y of the Treasury, Press Briefing by U.S Treasury Sec'y Tim

Geithner on the G20 Meetings (Sept. 24, 2009), available at http://www.g8.utoronto.ca/g20/2009/2009geithner0924.html.

2. Troy Reimink, Is the Government's Bailout Strategy Driving Up Unemployment?, GRAND RAPIDS PRESS BLOG (Nov. 9, 2009, 11:20 AM), http:/www.mlive.com/news/grandrapids/index.ssf/2009/11/is_the_governments_bailout_str.html (quoting Elizabeth Warren).
} 
Capital flows recognize no borders and take no responsibilities. Finance capital has no street address and financiers have no national or local loyalty - that's globalization. ${ }^{3}$ For the primary beneficiaries of finance, "[a]cross the nation, the most affluent Americans have been seceding from the rest of the nation into their own separate geographical communities .... Being rich now means having enough money that you don't have to encounter anyone who isn't., ${ }^{, 4}$ And according to economist Robert Scott, "[t]here's a huge difference between what is good for American companies versus what is good for the American economy."

Actually, the "first" signs of American economic retrenchment have been visible for decades in the structural deficiencies of finance capitalism, and the neo-liberal policies promoting its most virulent form. ${ }^{6}$

It is not that the economy has been broken for the last 30 years or so, but rather that it is working as it has been designed to work. During this time the reigning economic policy belittled the need for good quality jobs and economic security. In fact, we were told that the various laissez-faire policies pursued - unfettered globalization, deregulation of industries, financial market deregulation, a weakened safety net, and lower labor standards for minimum wages, overtime, discrimination, safety and health, and privatization of public services would all make us better off as consumers as goods and services became cheaper. It turned out that the predictable deterioration of job quality and greater economic insecurity created an economy that could only grow based on asset bubbles and rising household debt. For 30 years, policy levers have been pulled to help the well-off, and this policy orientation worked spectacularly on its own terms. ${ }^{7}$

Measuring the growth of productivity per worker in the economy over the last three decades, "a measure of what each individual worker, on average, contributed to the overall economy .... is equivalent to the

3. See James K. Galbraith, The Predator State, at xi-xii (2008).

4. Robert B. REICH, AFTERSHOCK: THE NeXt ECONOMY AND AMERICA'S Future 22 (2010).

5. Pallavi Gogoi, Where are the Jobs? For Many Companies, Overseas, USA TODAY (Dec. 28, 2010, 7:44 PM), http://www.usatoday.com/money/economy/2010-12-28-jobs-overseas_N.htm.

6. See generally GRETA R. KRIPPNER, THE POLITICAL ORIGINS OF THE RISE OF FINANCE (2011) (explaining various structural deficiencies created in the past four decades in finance capitalism).

7. Lawrence Mishel, Forward to Josh BIVEns, FaILuRE By Design: The STORY BeHIND AMERICA'S BROKEN ECONOMY 3-4 (2011). 
growth of income per worker as well. While average income per worker grew $59.0 \%$, median wages grew by just $11.2 \%$." 8 Even in the expansion of the first five years of the new millennium: "[i]n another recent report on the boom in profits, economists at Goldman Sachs wrote, "The most important contributor to higher profit margins over the past five years has been a decline in labor's share of national income."

United States' political leaders have consistently promoted paper capital accumulation, and therefore, simultaneously the greatest skew of distribution of wealth and concentration of wealth since the nineteenth century. ${ }^{10}$ It leads to a political-economic cart and horse, or chicken and egg problem. In 2010, four hundred individuals controlled more wealth than the bottom one-half of Americans (roughly one hundred and fifty million people). ${ }^{11}$ But it is not enough for finance capitalism to make the rich, richer. "Nearly all of the gains in wealth accrued to the upper fifth, with $40.2 \%$ of the gains going to the upper $1 \%$ of households and $41.6 \%$ going to the next wealthiest $4 \%$. Thus, the richest $5 \%$ of households obtained $81.8 \%$ of all the gains in wealth between 1983 and 2009 ," while the bottom four-fifths of households had less wealth in $2009(\$ 62,900)$ than in $1983(\$ 65,300)$, and black households had a median wealth of only $\$ 2,200 .^{12}$

The United States has engaged in systematically lowering the standard of living of most Americans, particularly looting the standard of living of the bottom half of American income, that is, predominantly workers and their families. "Since 1980 in particular, U.S. government policies have consistently favored the wealthy at the expense of working families .....13 By my count, the lowering of Americans' living standards has been or is being accomplished in promoting at least fifteen

8. Lawrence Mishel, What Workers Gave, and What They Got, ECON. POL'Y INST. (Mar. 17, 2011), http://www.epi.org/publication/what_workers_gave_and_what_they_got/

9. Steven Greenhouse \& David Leonhardt, Real Wages Fail to Match a Rise in Productivity, N.Y. TiMES, Aug. 28, 2006, http://www.nytimes.com/2006/08/28/business/28wages.html.

10. See David Leonhardt, Income Equality, N.Y. TMME, http://topics.nytimes.com/top/reference/timestopics/subjects/i/income/income_inequality/index.html (last updated Jan. 18, 2011); see also REICH, supra note 4, at 11.

11. Dave Johnson, 9 Pictures That Expose This Country's Obscene Division of Wealth, ALTERNET (Feb.

14 ,

2011),

$\mathrm{http}: / /$ www.alternet.org/economy/149918/9_pictures_that_expose_this_country $\% 27$ s_obscene_divis ion_of_wealth/.

12. Lawrence Mishel \& Heidi Shierholz, Sustained, High Joblessness Causes Lasting Damage to Wages, Benefits, Income, and Wealth, ECON. POL'Y INST. (Aug. 31, 2011), $\mathrm{http} / / \mathrm{www}$.epi.org/publication/sustained_high_joblessness_causes_lasting_damage_to_wages_bene fits_income_a/.

13. Paul Krugman, Losing Our Country, N.Y. TIMES, June 10, 2005, http://www.nytimes.com/2005/06/10/opinion/10krugman.html. 
strategic economic patterns or outcomes - sometimes through explicit policies, sometimes through inaction and the nod and the wink. No politician or "captain of industry" will baldly admit to intending these outcomes. No particular policy is necessary to the accomplishment of any particular pattern. But each pattern is supported by legal rules and political decisions (or non-decisions) that somehow end up supporting the effectiveness (though surely not the efficiency) of finance capitalism in the slow abandoning of America. In this process, court opinions are largely beside the point. Most legal power is deployed in legislation or administration, at all levels of government, whether in the mode of bureaucratic direct administration, or tax and subsidy, or permission or license, or via background assumptions of property or laissez faire. Law in this sense is always distributive, favoring or disfavoring, and this aspect of law is often unexamined by a legal academia fixated on appellate decisions. The whole is greater than the sum of its parts. Let me count the ways.

\section{First - Falling Real Wages}

In actual dollars in 2009, "the typical working-age household brought in $\$ 5,000$ less . . . than it did in the year 2000."14 As a result of the Great Recession, " $38 \%$ of families have been directly affected by wage, benefit, or hours reduction." 15 After a brief blip in the 1990s, average family income in real terms (adjusted for inflation) has fallen again to less than it was in 1970 - forty years and no wage gains. ${ }^{16}$ In the 1970s, economic policymakers lamented that this flat-lining resulted from lower productivity of American workers, either suffering ennui about their Taylorist assembly jobs, or from lack of reinvestment in labor promoting machinery, depending on observer taste. ${ }^{17}$ That has dramatically changed. Whether through speed-ups under threat of plant closures, or weeding out of non-competitive firms, or job redesign, American workers are leading in per capita productivity gains for the world.

But increased productivity has not translated into higher wages. ${ }^{18}$ From 1947 to 2007 , productivity rose almost $400 \%$, but average hourly

14. Great Recession: Falling Income, Rising Poverty, ECON. POL'Y INST., http:www.stateofworkingamerica.org/articles/view/15 (last visited Nov. 6, 2011).

15. Mishel \& Shierholz, supra note 12 , at 2 .

16. See REICH, supra note 4 , at $50-51$.

17. See id. at 52-53.

18. BARBARA EHRENREICH, THIS LAND IS THEIR LAND 95 (2008). 
compensation, while keeping pace with productivity increases until 1980, has remained essentially stagnant. ${ }^{19}$ Moreover, for many families, loss of income in absolute terms results from the loss of industrial production jobs, and their replacement by low wage service jobs, when there is any replacement at all. Since 2000, the United States has lost more than 3.78 million manufacturing jobs. ${ }^{20}$ Since December 2007, American households have lost more than six million jobs and now rest at a level of jobs less than in the year $2000 .^{21}$

Family income cannot be increased markedly by adding new jobholders when markedly fewer jobs are available to households. Younger workers experience income drops of considerably greater magnitude than older, experienced workers, ${ }^{22}$ and started with lower incomes than earlier decades to begin with. ${ }^{23}$ Furthermore,

[L]arge numbers of Americans will not be rehired unless they are willing to settle for lower wages and fewer benefits. The official unemployment numbers hide the extent to which Americans are already on this path. Among those with jobs, more and more people have accepted lower pay and benefits as a condition for keeping them. Or they have lost higher-paying jobs and are now in new ones that pay less. Or new hires are paid far less than the old .... Or they have become consultants or temporary workers whose pay is unsteady and benefits nonexistent. ${ }^{24}$

The one in seven Americans in poverty, most of them working, and most of them single women with children, are hit the hardest by loss of income.

An inconvenience to an affluent family - minor car trouble, a brief illness, disrupted childcare - is a crisis to them, for it can threaten their ability to stay employed. They spend everything and save nothing. They are always behind on their bills. They have miniscule bank accounts or none at all, and so pay more fees and higher interest rates

19. See REICH, supra note 4 , at $\$ 2$.

20. See U.S. CONG. BUdget OfFICE, FACTORS UNDERLyING THE DECline IN MANUFACTURING EMPLOYMENT SINCE 2000, at 2 (2008), available at http://www.cbo.gov/ftpdocs/97xx/doc9749/12-23-Manufacturing.pdf.

21. See Christopher J. GoOdman \& Steven M. MANCE, Employment Loss AND the 2007-09 RECESSION: AN OVERVIEW 4 (2011), available at http://www.bls.gov/opub/mlr/2011/04/art1 full.pdf.

22. See LAWRENCE Mishel \& JAREd BernsteIn, THE StATE of Working AMERICA: 199495 , at $146-47$ (1994).

23. Id. at 77 .

24. REICH, supra note 4 , at 66 . 
than more secure Americans. ${ }_{25}$. When the economy weakens, they slip back towards the precipice. ${ }^{25}$

The minimum wage has not proven to be the answer for the working poor. In 2003, a single adult with three children would need to earn $\$ 8.89$ an hour, full time, fifty-two weeks a year, just to reach the poverty line. $^{26}$ Even at today's rate of $\$ 7.25$ per hour, the minimum wage worker still falls more than $\$ 1.64$ per hour short, or $\$ 3,432$ short per year. ${ }^{27}$ And even at this level, the real value of today's minimum wage will be less than it was fifty years ago. ${ }^{28}$

\section{Second - Working Longer Hours}

Americans average less vacation time and more hours of work, five hundred more hours per family per year than in 1979, and pre-crash, the average American worker put in more hours than in any other advanced economic nation, three hundred and fifty hours more than Europeans, and more than the Japanese." "Families earning the median income now work about 3500 hours, on average, compared to 2800 hours in 1975. The 26 percent increase in hours worked mainly reflects increases in work outside of the home among women." ${ }^{30}$ This is one coping mechanism to raise family purchasing power although not enough to raise average real income. Of course the cost is time. The most pervasive labor movement demand in the nineteenth century was first for the six day week and ten hour day, and then later, the eight hour day. ${ }^{31}$ "There are twenty-four hours per day given us; eight of these should be for work, eight for sleep, and the remaining eight for recreation and in

25. DAVID K. SHIPLER, THE WORKING POOR: INVISIBLE IN AMERICA 4 (2004)

26. Id. at 9 .

27. See id. Relying on the same $\$ 8.89$ figure, if you subtract the modern minimum wage figure of $\$ 7.25$, in order to arrive at $\$ 1.64$, then multiply this figure based on Shipler's maximum earnings hypothetical of 52 forty-hour work weeks, then you get an income that is $\$ 3,432$ less than the $\$ 18,392$ figure the federal government used to define poverty for Shipler's example. Wage and Hour Division (WHD), U.S. DEP'T OF LAB. (Nov. 18, 2011, 4:05 PM), http://www.dol.gov/whd/minimumwage.htm.

28. Larry M. Bartels, Unequal Democracy: The Political Economy of the New GILDED AGE 224 (2008).

29. REICH, supra note 4 , at 62 .

30. Michael Greenstone \& Andrew Looney, The Great Recession May Be Over, But American Families Are Working Harder than Ever, BroOKINGS (July 8, 2011), http://www.brookings.edu/opinions/2011/0708_jobs_greenstone_looney.aspx.

31. See Samuel Parnell, MINISTRY FOR Culture \& Heritage, http://www.nzhistory.net.nz/people/samuel-parnell (last updated Oct. 31, 2011). 
which for men to do what little things they want for themselves.",32 Time-not just leisure, but self-improvement, gardening, politics. Time is one of the most valuable resources in our limited lives. Giving it up lowers our quality of life and that of our latch key children, whatever the income standard of living measured by income alone might remain. But of course working longer and harder, like eating, is "voluntary." Note that two ways working families tried to make up for falling income, more workers per family and working more hours, have essentially maxed out - and still real family income continues to fall.

\section{Third - Rising Unemployment}

In October 2010, the "official" unemployment rate, the U3, was up slightly at $9.7 \% .^{33}$ In August 2011 , after recovery (sic), it was still $9.1 \%{ }^{34}$ There will always be some level of unemployment in a market economy, but in the 1940 's, full employment on this measure was considered $2 \%$, up to $4 \%$ by the $1960 \mathrm{~s}$, and tolerated at $6 \%$ by the 1980 s. $^{35}$ Economists now are suggesting $8 \%$ or more would be consistent with recovery. ${ }^{36}$ But the U3 is only one of six "official" measurements of unemployment. ${ }^{37}$ The U6 includes the unemployed, those who are underemployed as part-time involuntarily, and most importantly, those who are able and willing but who have ceased looking for work. ${ }^{38}$ The U6 was $17.0 \%$ in October 2010 and $16.1 \%$ in July 2011 . $^{39}$ Currently, in hard hit states, it is most likely over $20 \%$. A society maintaining this level of unemployment for very long cannot be socially stable. "For the workforce overall, almost one in three - roughly $31 \%$ - were unemployed or underemployed at some point in 2009 ; for blacks and Hispanics the shares were $36 \%$ and $41 \%$, respectively." ${ }^{, 40}$

32. Id. (quoting Samuel Parnell, a leader of the nineteenth century labor movement).

33. See Table A-15: Alternative Measures of Labor Underutilization, U.S. BUREAU OF LAB. STATS., http://data.bls.gov/cgi-bin/print.pl/news.release/empsit.t15.htm (last modified Nov. 4, 2011) [hereinafter Table A-15].

34. See id.

35. See Bertram M. Gross, Unemployment: A Global Challenge, 492 AnNals AM. ACAD. POL. \& SOC. SCI. 186 (1987).

36. See Joseph E. Stiglitz, Freefall: America, Free Markets, and the Sinking of the WORLD ECONOMY 354-55 nn. 43-44 (2010).

37. See Table A-15, supra note 33 .

38. See Alternative Measures of Labor Underutilization for States, Fourth Quarter of 2010 Through Third Quarter of 2011 Averages, U.S. BUREAU OF LAB. STATS., http://data.bls.gov/cgibin/print.pl/lau/stalt1 1q3.htm (last modified Oct. 28, 2011).

39. See Table A-15, supra note 33.

40. Mishel \& Shierholz, supra note 12, at 2-3. 
The costs of unemployment are high economically:

The common discussion of unemployment and the need for job creation vastly understates both the economic damage rendered by persistently high unemployment and the extent of the population affected. Just the simple fact that the economy is below its potential production of goods and services means that each person (man, woman, and child) lost roughly $\$ 3,000$ in 2009 and another $\$ 2,850$ in 2010 , and more losses will come before we return to full employment. These significant costs clearly reflect lower employment and fewer hours of work. But the adverse effects of persistently high unemployment include lower wages and benefits for those who have jobs. And they also include long-term "scarring": young people who cannot get a proper footing at the start of their careers suffer lower lifetime earnings. ... 41

Nor is damage just economic. Social morbidity increases crime, domestic violence, illness, and other social ills. For example, "a one point rise in unemployment is associated with a $2.2 \%$ increase in heart attacks and a 5.6\% increase in homicides." 42 Twenty years after the 1980's recession,

[T]he net loss to a displaced worker with six years of job tenure is approximately $\$ 164,000$, which exceeds 20 percent of the average lifetime earnings of these workers. These future earnings losses dwarf the losses associated from the period of unemployment itself. . . [J]ob loss also has negative economic and noneconomic effects on workers health, their families and their communities. Men with high levels of seniority when they are displaced from their jobs experience mortality rates in the year after unemployment 50 to 100 percent higher than otherwise would be expected .... These elevated rates of mortality are still evident even twenty years after the job loss and may reduce these workers' life expectancies by twelve to eighteen months for a worker who loses his job at age forty. The children of these workers also appear to suffer. Children whose fathers were displaced have annual earnings about 9 percent lower than similar children whose fathers did not experience an employment shock .... ${ }^{43}$

\footnotetext{
41. Id. at 1 .

42. MISHEL \& BERNSTEIN, supra note 22 , at 82.

43. Michael GREenstone \& ADAM LoONEy, AN ECONOMIC STRATEGy to RENEW AMERICAN COMMUNITIES (2010), 7-8 available at http:/www.brookings.edu/ /media/Files/rc/papers/2010/10_renew_communities_greenstone_loone y/10_renew_communities_greenstone_looney.pdf; see generally WILLIAM JULIUS WILSON, WHEN
} 
"The share of children with an unemployed or underemployed parent rose from $9.1 \%$ (6.4 million) in 2007 to $18.3 \%$ (13.0 million) in 2010," rising to one in four for African-American and Hispanic children. $^{44}$

\section{But Fourth - Rising Length of Unemployment}

More Americans as a percentage have been unemployed for more than one year than ever before; $25 \%$ have been unemployed for over a year. ${ }^{45}$ The impact is felt disproportionately in economically depressed regions. $^{46}$ In 2011 , a steady $45 \%$ of unemployed workers have been unemployed for over six months. ${ }^{47}$ Further compounding job loss for most of the unemployed, by 2007 , only $40 \%$ of the unemployed even initially qualified for unemployment compensation, most of the remaining failing the requirement of seventeen weeks of continuous full time employment, with a lower percentage attributed to the reasons for leaving prior employment. ${ }^{48}$ Ironically, the collapse of the mortgage market as a result of the bursting of the securitized mortgage bubble has worsened the personal welfare of workers in declining communities by making their houses unsellable, which makes it infeasible to re-locate to communities with available jobs of any kind. Geographic mobility is at "a historic low." 49

\section{And Fifth - The Falling Employment to Population Ratio}

It is not just the rate and length of unemployment sapping family living standards. The number of people employed compared to our

WORK DISAPPEARS (1996) (exploring the effects of unemployment on urban homes and communities).

44. Mishel \& Schierholz, supra note 12, at 2.

45. See Michael GReEnStone \& ANDrew LoONey, The Great Recession's Toll on LONG-TERM UNEMPLOYMENT 1 available http://www.hamiltonproject.org/files/downloads_and_links/1010_jobs_long_term.pdf [hereinafter GREENSTONE \& LOONEY, THE GREAT RECESSION'S TOLL].

46. See Andrew Looney \& Michael Greenstone, Leave No Community Behind, BrookINGS, (Oct. 8 2010), http://www.brookings.edu/opinions/2010/1008_communities_greenstone_looney.aspx [hereinafter Looney \& Greenstone, Leave No Community].

47. See News Release, Dep't of Labor, The Employment Situation - October 2011 (Nov. 4, 2011), available at http://www.bls.gov/news.release/archives/empsit_11042011.pdf [hereinafter DOL News Release].

48. See REICH, supra note 4 , at 55 .

49. Looney \& Greenstone, Leave No Community, supra note 46. 
population is dropping, to the lowest point since the Great Depression. ${ }^{50}$ That means fewer incomes with lower wages supporting increasing dependents. The phenomenon of children over thirty and parents moving in to their parent's/children's homes is now familiar to the middle class as well as the poor who have long lived in extended families by necessity.

\section{And Sixth - Increasing Jobs Gap}

If the American economy were to produce an extremely optimistic 200,000 jobs a month, it would take twelve years to produce the 11.8 million additional jobs necessary to return to pre-Great Recession employment levels, that is, the same percentage of workers employed and contributing therefore to family income. ${ }^{51}$ June 2011's jobs gap increased to 12.3 million jobs, up 150,000 just in the month of May. ${ }^{52}$ Clearly, the official end of the Great Recession has not led to more jobs. In the latter half of 2011 , the economy is stuck at creating less than 100,000 jobs per month, ${ }^{53}$ an insufficient number to even keep pace with new job seekers entering the labor market due to population growth. In recent months the job creation rate has dropped to 72,000 jobs per month, roughly half the number necessary not to widen the gap further. There are currently four unemployed workers for every new job created. ${ }^{54}$ And it could have been worse - it is estimated that without the American Recovery and Reinvestment Act of 2009, another three to four million jobs would have been added to the gap, and the official unemployment rate would have reached $12 \%{ }^{55}$

\section{And Seventh - U Shaped New Job Creation}

By far the greatest number of new jobs are in the low-wage service

50. See Mathew Bandyk, Is Unemployment the Worst Since the Great Depression?, U.S. NEws (Aug. 27, 2009), http://money.usnews.com/money/business-economy/articles/2009/08/27/isunemployment-the-worst-since-the-great-depression.

51. GREENSTONE \& LOONEY, ThE GREAT RECESSION's TOLL, supra note 45, at 2.

52. Id.

53. See Christopher S. Rugaber, Unemployment Drops in 25 States, FISCAL TIMES (Oct. 21, 2011), http://www.thefiscaltimes.com/Articles/2011/AP-Unemployment-Drops-in-25-

States.aspx\#pagel.

54. Compare DOL News Release, supra note 47 (finding the total number of unemployed is 13,900,000), with News Release, Dep't of Labor, Job Openings and Labor Turnover - November 2011 (Nov. 8, 2011), available at www.bls.gov/news.release/pdf/jolts.pdf (finding the total number of open jobs is $3,400,000$ ).

55. BIVENS, supra note 7 , at 35,41 . 
sector, with a smaller but still large number of high paying, high education or skill jobs created in the information/knowledge sector ${ }^{56}$ Jobs are being lost rather than created in mid-range salaried employment. De-industrialization and/or automation causes part of the loss, especially in mid-management, but financial services, including insurance, have been hit hard more recently. And so the middle class disappears.

\section{Eighth - Lower Union Density}

Union density in the private sector workforce has reached its lowest point since the nineteenth century, $6.9 \%{ }^{57}$ The future prospects are mixed at best, given the substantial shift to a service dominated economy ( $80 \%$ of the U.S. workforce), a sector whose small firm and geographic dispersion of customers make organization difficult. ${ }^{58}$ Even if organized initially, low income service workers often do not generate sufficient dues levels to underwrite greater organizing. Union wages, which are historically higher than unorganized workers even in the same industry, set a competitive wage standard that competing firms must closely meet to gain the best workers in a competitive labor market. If union wages are prevalent in a region, the union rate functions much like a higher minimum wage floor. All wages must settle in relation to the minimum wage and union rate. The lower the union density the less, if at all, this latter rate matters, and the lower the wages that will be paid throughout the affected labor market. ${ }^{59}$ It has been estimated, that "the massive decline in union membership since the late 1940s has probably depressed the real value of the minimum wage by about $40 \% . " 60$ Almost all wages are relative to other wages in a relevant labor market.

More than wage effect, unorganized workers have no bargaining leverage in a falling market. Over two thirds of the American work force is employed at-will, which means they can be fired at any time for

56. See David AUtor, The Polarization of Job Opportunities IN THE U.S. Labor MARKET: IMPLICATIONS FOR EMPLOYMENT AND EARNINGS 2 (2010), available at http://www.americanprogress.org/issues/2010/04/pdf/job_polarization.pdf.

57. Steven Greenhouse, Union Membership in U.S. Fell to a 70-Year Low Last Year, N.Y. TIMES, Jan. 21, 2011, http://www.nytimes.com/2011/01/22/business/22union.html.

58. See Kenneth M. Casebeer, Of Service Workers, Joint Employment, Contracting Out, Legal Consciousness, and the University of Miami, 56 BUFF. L. REV. 1059 (2008).

59. See Damon A. Silvers, How a Low Wage Economy with Weak Labor Laws Brought Us the Mortgage Credit Crisis, 29 BERKELEY J. EMP. \& LAB. L. 455, 463-64 (2008) (showing employer provided benefits have decreased with union density).

60. BARTELS, supra note 28 , at 226. 
good reason, bad reason, or no reason at all. ${ }^{61}$ With high unemployment, a long-term employee who has had some wage increases should expect to be fired and a new, cheaper worker hired. See for example the lack of long-term workers in the retail grocery business.

\section{But Ninth - The Social Wage is Being Lowered}

One might ask, "What social wage in the United States?" Whatever there was, it is going away fast. The Great Recession has devastated local and state governments - funds for police, fire, hospitals, parks, social welfare, and education are taking devastating hits. ${ }^{62}$ User fees are more prevalent. Risks are increasingly transferred to employees as assumption of risk. Unemployment insurance, never universal, now determines eligibility such that $1 / 3$ of the unemployed qualify for the program, ${ }^{63}$ and those eligible face bankrupt state trust funds, and bills in Congress to cut the length of time recipients receive benefits despite longer periods of unemployment. For the majority of Americans, the cuts are even worse as tax bases are reduced by wealthy citizens who are able to secede from larger communities, or establish gated communities, and thereby buy private services that will already be priced lower for them. Because of these severed connections center cities are left servicing needier, poorer populations - more services necessary, higher costs to provide more extensive versions of services. ${ }^{64}$

\section{Tenth - Increasing Regressivity of Taxes}

The highest bracket for federal income tax purposes has dropped from $70-90 \%$ in the 1970 s to $25-39 \%$ at present. ${ }^{65}$

At the same time, the "New Federalism," aided and abetted by the Supreme Court, has abdicated national responsibility for service delivery

61. See, e.g., Thomas R. Schultz, Note, State Law Protection of At-Will Employees Who 'Blow the Whistle,' 65 U. DET. MERCY L. REV. 551, 551 (1988).

62. The current state financial crisis and dispute over funding state services in Wisconsin is but one example of state governments that have had to cut state services, such as education, because of high state government debt. See Alex Morrell, Wisconsin Gov. Scott Walker Signs State Budget in Green Bay Area, GREEN BAY PRESS GAZETTE, June 27, 2011, http://www.greenbaypressgazette.com/article/201 10627/GPG0101/106270493/Walker-signs-statebudget-Ashwaubenon-hundreds-protesters-gather-outside?odyssey=tab|topnews|img|GPG-News.

63. See Kathy Lohr, Unemployed Without Benefits: A Couple's Struggle, NPR (Jan. 14, 2009), http:/www.npr.org/templates/story/story.php?storyld=99170822.

64. See REICH, supra note 4, at 99.

65. Id. at 55 . 
and intervention in social ills, shifting service provision to state and mostly municipal governments, without increasing federal transfer grants to local governments. In 1991, the bottom $20 \%$ of households of four paid $13.8 \%$ of their income after federal deductions to state and local government, the next $20 \%$ paid $10.7 \%$, while the top $20 \%$ paid just over $7 \%{ }^{66}$ (while this data is old, there is little reason to believe the general disparity has changed much since then). This level of government principally relies on property taxes whose incidence falls on renters through rent payments, and while tied to property value assessments for all homeowners, such taxes do not use progressive rates per assessment. Sales taxes as an alternative funding source impact a higher percentage of income for the poor and middle class because at those income levels virtually $100 \%$ and sometimes more of income is spent compared to the wealthy. ${ }^{67}$ State and Local expenditures will continue to decline in 2011 , half of the states will have revenues decline, tax receipts will decline at the fastest rate in 50 years, and municipal bankruptcies will rise due to more than $\$ 6$ billion in bond defaults during the present recession. Detroit and Los Angeles are contemplating bankruptcy. ${ }^{68}$ Public sector jobs are being cut by 35,000 workers per month, totaling over half a million lost in the last three years. ${ }^{69}$

\section{Eleventh - Increasing Costs of Consumer Debt}

Americans made up for falling family income and job losses by borrowing. At the beginning of the crash, Americans were spending at an average of $138 \%$ of their disposable income. ${ }^{70}$ Putting aside entirely rampant mortgage fraud and sub-prime mortgage traps, consumers cashed out equity in their homes and amassed large numbers of easily available credit cards and lines, and student loans. ${ }^{71}$ Now that the credit bubble has burst, the cards are not available, or if they are, only at interest rates up to $79.9 \%$ annually! $!^{72}$

66. MISHEL \& BERNSTEIN, supra note 22, at 105 tbl.2.13.

67. REICH, supra note 4 , at 55 .

68. See Jim Haughney, State and Local Government Spending to Decline Again in FY' 11 , REED CONSTRUCTION DATA (May 25, 2010), http:/www.reedconstructiondata.com/constructionforecast/news $/ 2010 / 05 /$ state-and-local-govemment-spending-to-decline-again-in-fy-1 1/.

69. Mishel \& Shierholz, supra note 12, at 9.

70. REICH, supra note 4, at 23.

71. See EHRENREICH, supra note 18 , at 50, 80-81.

72. Connie Prater, Issuer of $79.9 \%$ Interest Rate Credit Card Defends its Product, CREDITCARDS.COM, http://www.creditcards.com/credit-card-news/first-premier-79-rate-fees-creditcard-1265.php (last updated Feb. 12, 2010). 
The low-credit, high-cost cards, known as fee harvesting credit cards, are issued to people with bad credit or no credit history and feature credit limits of $\$ 500$ or less. Issuers typically charge a slew of fees at the outset to compensate for the risk of lending to people with poor repayment histories. Starting Feb. 22, 2010, the law will limit upfront fees to no more than 25 percent of the credit limit on the account. ${ }^{73}$

Touted loan modification is largely available only to those who probably did not need it to keep their homes. The bailed out banks prefer to lend to large corporations that just sit on the cheap money awaiting better times for future investments. ${ }^{74}$ Bailing out the banks made them profitable, but did not lead to new investment producing more jobs. Only the stimulus of increased federal spending under the American Recovery and Reinvestment Act prevented even more net job loss. Private debt is no longer available to consumers trying to mortgage a standard of living to be repaid in the future but again the former overextension was "voluntary."

\section{Twelfth-Proposed Elimination of the Mortgage Interest Deduction}

Ending the mortgage interest exemption is part of the proposed package to reduce the federal deficit. Aside from whether this would be counterproductive to recovery, ending this subsidy to home ownership cuts away the only realistic way that lower and middle income families have been able to "save." The historical increases in the value of family homesteads in the past six decades could be cashed in for retirement after the family had left the nest. Surely cashing out equity as debt has reduced this "savings" of many pre-crash homesteads already. But new families and the young generally will be priced out of the American Dream. We will become a nation of renters, subject to increasing housing costs as a result of inflation and scarcity of new housing stock, and this will not be "voluntary.",

73. Id.

74. See Justin Lahart, Companies Cling to Cash: Coffers Swell to 51-Year High as Cautious Firms Put Off Investing in Growth, WALL ST. J., Dec. 10, 2010, http://online.wsj.com/article/SB10001424052748703766704576009501161973480.html; see also STIGLITZ, supra note 36, at 33 ("By taking advantage of these low-cost funds and lending them at much higher interest rates-reduced competition in banking meant that they had more power to raise lending rates-the banks would gradually get recapitalized ....").

75. RICHARD D. WOLFF, CAPITALISM HITS THE FAN: THE Global ECONOMIC MELTDOWN AND WHAT TO DO ABOUT IT 145-47 (2010). 


\section{Thirteenth - Effects of Inequality of Income and Wealth}

Rising inequality is a cause as well as an effect of lowering living standards. It is a well promulgated, as well as an instrumental, myth that investment depends on savings rates. Savings have not clearly correlated to investment since the Depression. Rather, investment depends on demand for new products. ${ }^{76}$ The middle class and below spend all their money on goods and services. The rich do not. The more that economic surplus is funneled to the rich, the less demand for the necessities of life. ${ }^{77}$ If there is a rising amount of un-invested money that is available to a narrowing population sector, the price of luxury goods and particularly such services may skyrocket, but overall production, and therefore jobs, will not. ${ }^{78}$

\section{Fourteenth - Investment in Production/Investment in Finance Ratio}

As wealth increasingly concentrates but demand for ordinary products for life decreases as family incomes fall, investment decreases in production (the so-called real economy) and greater returns are directed toward speculation in the financial future (the so-called paper economy) ${ }^{79}$ As a result:

In short, America's financial markets had failed to perform their essential societal functions of managing risk, allocating capital, and mobilizing savings while keeping transaction costs low. Instead, they had created risk, misallocated capital, and encouraged excessive indebtedness while imposing high transaction costs. At their peak in

76. See Gerald Friedman, The Crisis and the Economists: A Guide to the Perplexed, 51 LAB. HIST. 345, 348, 350 (2010) (stating inter alia that "the economy is limited by the lack of effective demand for investment and consumption").

77. See STIGLITZ, supra note 36, at 19 (explaining that without the bubble that has been sustaining the American economy, "aggregate demand-the sum total of goods and services demanded by households, firms, government, and foreigners-would have been weak, partly because of the growing inequality in the United States . . . ); see Timothy A. Canova, Financial Market Failure as a Crisis in the Rule of Law: From Market Fundamentalism to a New Keynesian Regulatory Model, 3 HARV. L. \& POL'Y REV. 369, 371 (2009) ("A top-heavy distribution of income could drain purchasing power from those segments of the population most likely to spend and maintain demand for those goods and services-in economic terms, those with a high marginal propensity to consume").

78. See STIGLITZ, supra note 36 , at 191 ("[T] growing inequality contributes to the problem of lack of global aggregate demand-money is going from those who spend it to those who had more than they needed").

79. See Judith Stein, Pivotal Decade: How the United States Traded Factories for FINANCE IN THE SEVENTIES (2010). 
2007, the bloated financial markets absorbed 41 percent of profits in the corporate sector. ${ }^{80}$

Here too, the United States government "chose the short-term preferences of the financial sector over the short-term preferences of the manufacturing sector and the long-run health of the overall economy." Speculation and risk inevitably increased. As new legal versions of derivative securities are devised and marketed, this paper is bid up and up with no relation to any real assets which may or may not have secured the original debt issue. It is a parallel phenomenon to the margin buying of stocks preceding the Great Crash of the stock market in 1929. As long as someone else continued to buy, anticipating future further bidding, enormous fortunes were made and cashed out, and then begun again. Ponzi, pure and simple. But, if any of the players called the debt, the pyramid would, and did, collapse. Before the crash, more GDP value had swung into paper assets than were retained in productive assets. ${ }^{82}$ Again more paper speculation, less increase in "real" production, and fewer, if any, new jobs. The short history of finance capitalism has been nothing but a series of bubbles, building and bursting. The whole game is to leave someone else holding the bag musical chairs, and as the chairs are removed (real assets foreclosed) only one is able to sit (probably in a foreign tax haven).

\section{Finally, Fifteenth - Pursuit of "Free" Trade}

This last is tricky, but "Free Trade" is also an instrumental path to increase return to certain capital.

[U.S.] multinationals have fired 2.9 million workers here, they have hired 2.4 million abroad. Some of these workers make parts to be shipped here, but when the parts are assembled into the gizmos or widgets that we sell abroad, we count them as 'exports.' 'Isn't that true for other countries?' Sure-but the United States is much worse, because there is no government check (as in China) or organized labor check (as in Germany) to keep employment here. Our real trade deficit is much worse ... ${ }^{83}$

\footnotetext{
80. STIGLITZ, supra note 36 , at 7.

81. BIVENS, supra note 7, at 57.

82. See Ozgur ORHANGAZI, FINANCIALIZATION AND THE U.S. ECONOMY (2008).

83. Thomas Geoghegan, What Would Keynes Do?, NATION, Oct. 17, 2011, http:/www.thenation.com/article/163673/what-would-keynes-do.
} 
Importing cheap goods from abroad produced under artificially low labor standards, purchased through loans to the United States public and private sectors from countries in trade surplus with the United States, creates short term return to the international financial sector.

[P] urchase of dollar-denominated debt helped U.S. financial firms by providing them access to cheap money that they could then lend out at a premium. But these purchases also hammered manufacturing firms and their workers producing in the United States, as they led to a large increase in the value of the U.S. dollar. The rising dollar made U.S. exports expensive on world markets while other nations' imports became artificially cheap to American consumers. The result was a trade deficit and hemorrhaging jobs in American manufacturing. ${ }^{84}$

It did not lead to investment in export supplying new production and new jobs in the manufacturing sector in the United States. Instead industry is bleeding out of the United States. The middle class is destroyed. New fiscal stimulus is less effective because the multiplier effect is reduced to the extent new income goes to buy more imports rather than all U.S. manufactured goods and services.

"Free Trade will raise all boats." Except that under globalization, it does not. Take NAFTA. Even though Free Trade would cost the United States manufacturing jobs, these losses, it was promised, would be more than made up for in demand for our exports as the new jobs in Mexico would generate new demand for our products. ${ }^{85}$ It did not happen. Few, if any, aggregate jobs were created in the United States because the exported jobs to Mexico paid wages there that did not pay more than those in the existing Mexican domestic labor market, and the new jobs substituted for jobs that had been part of the internal Mexican economy. New job entrants competed with the displaced for fewer jobs at low wages. It was therefore still worth the increased risk of illegally entering the United States to compete for low wage jobs, keeping low wage service jobs as low paying as possible. Increased labor market competition coupled with high unemployment act as a reverse minimum wage in lowering all relative wage rates. Offshoring is just a larger category of such effects. As global competition lowers the profit margin

84. BIVENS, supra note 7, at 57 .

85. See generally ROBERT E. SCOTT, HEAdING SOUTH: U.S. - MEXICO TRADE \& Job DISPLACEMENT AFTER NAFTA 6 (2011), available at http://www.epi.org/page//BriefingPaper 308.pdf (discussing the stated objectives of NAFTA, namely increased demand for exports in the U.S., and the actual consequences of NAFTA, including job-displacement and trade deficits). 
of still producing firms, the most controllable factor of production is squeezed, that is, labor cost. First the givebacks, then the closures, then the exporting of production to lower production cost locations, then the global race to the bottom. The cycle then returns home and becomes more vicious, forcing still lower wage rates and lower union density.

\section{Recipe: Cascading Lower Aggregate Effective Demand}

The legal and political choices that either facilitate or ignore these fifteen patterns that lower the standard of living of the majority of the American people are hardly unconnected. These fifteen developments are produced as part of the neo-liberal promotion of maximizing a particular form of capitalism. It should not be surprising, therefore, that the effects of each development reinforces other developments. Those effects cascade into downward spirals. Finance capitalists do not care about the "real" economy and are therefore indifferent to increasing production. Less investment in this part of the economy ironically increases competition over the remaining product market because of falling product demand, putting increasing pressure on labor costs. The resulting offshoring increases overcapacity of production worldwide and that also exerts downward pressure on wages and jobs. What economic surplus is still available goes to owners and is not reinvested in superfluous new jobs. Wages must be lowered more. Less money is available to support any social wage compensation. Lower incomes lead to less ability to spend. Credit is no longer an escape valve. Lower demand and offshoring create unemployment. Re-employment is forced into lower paying service jobs. Unemployment becomes lengthy and many never return to jobs. Fewer people are employed and family income drops. Jobs are lost, jobs pay less, costs of necessities and taxes increase-all allowing less purchasing by families. ${ }^{86}$

Finance capitalists seemingly never care; to the extent they invest in production, they will do so not to create more aggregate jobs, but to exploit lower labor cost populations elsewhere, in turn lowering wages necessary to any production left in the United States that is not geographically mobile. Corporate America has plenty of money to create new jobs, as witnessed by the fact that those corporations in the last twelve months created 1.4 million new jobs overseas but less than 1 million new jobs in the United States. ${ }^{87}$ Taking the fifteen developments

86. See Stiglitz, supra note 36 , at 55 .

87. See Gogoi, supra note 5 . 
together, average Americans have less and less to spend and that decrease impacts lower income families the most. But structurally, and more dangerously long-term for the economy, aggregate effective demand for production stagnates or declines in America. ${ }^{88}$ The GDP may well recover on paper, and financial services after the bail outs have revived to the point that high level management still receives obscene bonuses, but unemployment will remain in double digits as measured by the U6 for the next decade because the United States has no incentive to care about the standard of living of most Americans. Simply put, individual Americans are no longer necessary. Falling aggregate demand in the United States, if offset by other populations, may even help our trade deficit (remember Secretary Geithner).

\section{Weather Report: Substantially Lower Standard of Living, Occasional Deep Depressions, Followed by Increasing Social Morbidity, and Greater Likelihood of Political Turns Toward the Authoritarian}

Lower standards of living and high real unemployment, contrasting with the opulence supported by increasing concentration and inequality of wealth, will have consequences: desperation produces crime beyond the capacity to support an increasing percentage of the population as incarcerated (the U.S. alternative to poor houses). Desperation produces violence, particularly domestic violence. ${ }^{89}$ As infrastructure collapses, urban problems of concentration and decay multiply. Those who can afford to do so will escape because our laws and policies support the "individualistic" ideology necessary to unbridled accumulation. Where does the accumulated anger go? The past answers that the immiseration of the middle and working classes turns into authoritarianism. ${ }^{90}$ It could get worse:

The cost for the United States of these failures [to boost the economy] will be high: not only does it face the risk of another major crisis within the next fifteen years, not only have the vast array of problems barely been addressed, but the divide between Wall Street and Main

88. See Hyman Minsky, Stabilizing an UnSTABle ECONOMY (2008).

89. Alberto Alesina \& Roberto Perotti, Income Distribution, Political Instability, and Investment, 40 EUR. ECON. REV. 1203 (1996) (finding that in a sample of 71 countries for the period of 1960-85, socio-political instability, which include variables such as domestic violence and assassinations, increase as income inequality increases).

90. Robert Andersen \& Jocelyn A.J. Evans, Social-Political Context and Authoritarian Attitudes: Evidence From Seven European Countries (Ctr. for Research into Elections \& Soc. Trends, Working Paper No. 104, 2004), available at www.crest.ox.ac.uk/papers/p104.pdf. 
Street (both businesses and workers) has become wider, and with that growing divide, the sense of community and the ability to resolve common problems has become ever weaker. ${ }^{91}$

\section{Shelter in the Storm - What Can be Done?}

The solutions for the decline in most American's standard of living, redistribution of wealth, or at least income, is as obvious as it is obviously not going to be pursued. The Tea Party era decrees no redistribution of wealth, either directly through taxation and grants, or indirectly through greater governmental expenditures, even to support rebuilding infrastructure or increased education and skill training for all.

Joseph Stiglitz propounds an aggressive mixture of fiscal, trade, and monetary policy aiming at a full employment economy. ${ }^{92} \mathrm{He}$ suggests devaluing the dollar to boost manufacturing for export and reducing imports. ${ }^{93}$ This would provide a big boost to job creation, but at the expense of finance sector profits and distribution upward to the wealthy, promising political opposition. Increasing taxes for more expenditures to support aggregate demand are unlikely for the same reason. Monetary policy cannot send interest rates below zero and it will not help low-income families to make more debt possible. We have maxed out monetary policy.

Other economists, such as Robert Reich, argue for massive redistribution of wealth, in large part to support increased aggregate demand. ${ }^{94}$ Redistribution of wealth flowing to the vast majority would be entirely spent. He would adopt a large environmental and energy "carbon" tax, increasing marginal tax rates on the wealthy, and a corporate "severance" tax imposed when companies cut or offshore jobs, combining to fund the scheme. 95

These types of proposals attempt to restart the economy and wipeout job loss but do not in and of themselves improve living standards or prevent future speculation-induced collapses. As James K. Galbraith argues, "The solution is not another 'stimulus' - a term that stinks of needles and quick fixes. The solution has to be a long-term strategy: both a new direction for economic activity and new institutions

\footnotetext{
91. STIGLITZ, supra note 36 , at 342 .

92. Id. at 63,77 .

93. Id. at 233.

94. See REICH, supra note 4, at 3-5.

95. See id. at 130-34.
} 
to provide the money." ${ }^{, 96}$ Josh Bivens, writing for the Economic Policy Institute, would start with a substantial increase in the minimum wage and then add a panoply of policies to target job creation more directly and stabilize demand for those products, thus in turn stabilizing jobs. ${ }^{97}$ But even with explicit jobs policies, ${ }^{98}$ what if governments, particularly the federal government, are hamstrung by the beneficiaries of the past three decades in raising taxes for these approaches or raising the minimum wage? Are there any other agents to increase demand for manufactured products and the jobs that produce them, and at wages above an inadequate minimum?

One possibility would be to return to the local. Community Syndicalism $^{99}$ denies the public-private distinction essential to legitimating "cowboy" investment, the unrelenting focus on short-term profits and the race-to-the-bottom of labor standards. What is needed is a model of economic production that maximizes long-term incentives to invest in new production that would maximize job creation and maximize job stability.

What do the Germans, with their hefty trade surplus, do? First, they have a whole different type of corporation-with workers making up half the directors on the board. And workers have privileged positions in the firms, real power and responsibility. It doesn't guarantee that corporations invest, but it's a big help to have workers in director chairs sitting in the boardrooms. In addition, the Germans have government-sponsored banks, like the Sparkassen, that lend to businesses. We have the Federal Reserve printing money like crazy, but the banks sit on it and don't lend it out, just as American CEOs who have never met a worker .... ${ }^{100}$

The key to creating new local leverage on globalized markets is to split capital asset ownership and enterprise ownership. This could be done by collectivizing local wealth within an investment pool managed by a democratically elected special service district. Funded by a rolling tax on future beneficiaries, the district could only invest in local land,

96. James K. Galbraith, Fixing the Economy: We Got it Wrong, L.A. TIMES, Aug. 15, 2011, http://articles.latimes.com/2011/aug/15/opinion/la-oe-galbraith-economics-20110815.

97. See BIVENS, supra note 7.

98. See American Jobs Act of 2011, S. 1549, 112th Cong. (2011).

99. Kenneth M. Casebeer, Community Syndicalism for the United States: Preliminary Observations on Law and Globalization in Democratic Production (Miami Law Research Paper Series, Paper No. 2011-36, 2011), available at http://papers.ssm.com/sol3/papers.cfm?abstract_id=1966172\#.

100. Geoghegan, supra note 83 , at 17 . 
buildings, and machinery, which would be owned by the district, and provide operating capital to new enterprises. Groups representing potential workers would "bid" on leasing these capital resources longterm at a nominal rate by proposals for production enterprises promising long-term niches in global supply chains. Once the bid is accepted, the workers would own the enterprise production and manage the enterprise democratically. The locality would not want to lose the created jobs improving their local economic and tax base, and workers would not cash out an enterprise whose value is entirely in cash flows supporting higher wage jobs than the private investment market did or would support. The enterprise could be viable because no profits need be generated except for retained earnings to adapt to new technologies.

Many plants are closed not because they fail to make a profit, but because they fail to make enough profit to hold the decision-maker's interest when compared to some other marginally more profitable opportunity. When management fails to reinvest and modernize, productivity and profit margins most often do decline, thereby reinforcing the initial, casual decisions whose rhetoric often either places blame at the feet of labor, or speaks of these developments as if they constituted some natural and inevitable evolutionary path beyond anyone's control. ${ }^{101}$

Local leveraging of the global market to preserve higher wage jobs would at least help working families' standards of living and provide a new economic model less susceptible to upward wealth distribution caused by financialization. By itself, it is surely not enough. No single approach will reverse decades of neglect and worse.

\section{Working Families' Futures}

Make no mistake-Americans have been abandoned. Once before, Herbert Hoover's Secretary of the Treasury, Andrew Mellon, prescribed the end to the Great Depression: "[1]iquidate labor, liquidate stocks, liquidate the farmer, liquidate real estate. ... It will purge the rottenness out of the system . . . People will work harder ...."102 This formula has resurfaced in a new guise - a legal system of regulation and legislation, of deregulation and regressive taxes, subsidies for the

101. Fran Ansley, Standing Rusty and Rolling Empty: Law, Poverty, and America's Eroding Industrial Base, 81 GEO. L.J. 1757, 1764 (1993).

102. Herbert HoOver, The Memolrs of Herbert HoOver: The Great Depression 1929 -1941 , at 30 (1952). 
wealthy combined with cuts of public support for the working poor, and promotion of finance at the direct expense of lost jobs and lower wages. We have as a people reached the point that our own standard of living has been and is being systematically and intentionally lowered and exploited. Law is the handmaiden of abandonment. I fear the future because I see how it has been done. I have counted the ways.

For probably well more than three quarters of us, our children will never surpass us economically or educationally. ${ }^{103}$ Our sons and our daughters, yes, and I am afraid for them all. I am afraid too for $m y$ children, $m y$ son and $m y$ daughter.

103. See REICH, supra note 4 , at 91 